\title{
State department to hire science adviser
}

[WASHINGTON] The US Department of State is to appoint a science adviser in response to widespread criticism that it has been neglecting science and technology. Officials at the department, which is responsible for US foreign affairs, say the individual appointed will be a "distinguished person" from the science community.

Melinda Kimble, assistant secretary of state for oceans, environment and science, told a meeting at the National Academy of Sciences in Washington last week that the adviser would work directly with senior officials at the department, including herself and Stuart Eisenstadt, the under-secretary for global affairs, to "work with scientific issues at the state department and to develop a science policy" for it.

Kimble said after the meeting that the recruitment of the adviser was at a preliminary stage, but that she hoped to select someone this summer.

The meeting was held to introduce a new science and technology agreement between the United States and the European Union (see Nature 390, 543; 1997). Kimble told the meeting that problems with the department's handling of science issues had arisen because of overall cuts in its budget.

She claimed that the budget had fallen by $\$ 5$ billion since 1985, "when science and technology seemingly were a higher priority on our national agenda". (According to the 1999 budget book, the department's budget

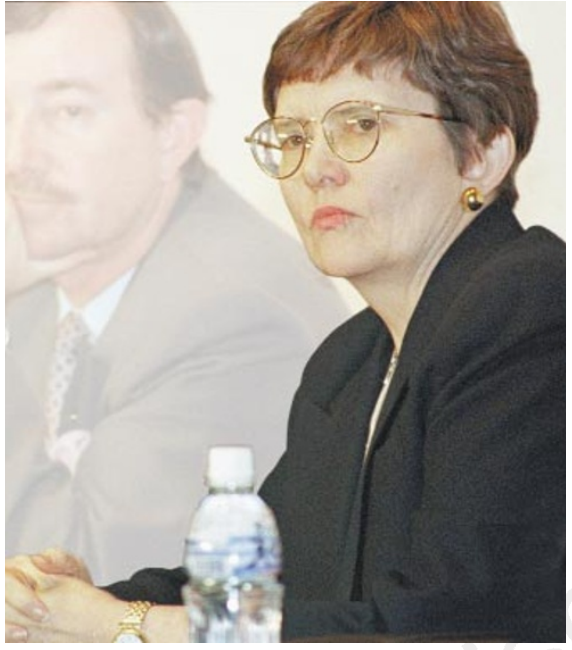

Kimble: budget cuts caused problems for the state department's handling of science issues.

in fact expanded from $\$ 3$ billion in 1985 to $\$ 5$ billion last year, approximately in line with inflation.)

Kimble said there were "certainly some grounds" for recently expressed concerns and criticism "due to the perception that we are de-emphasizing science". She added that the department had responded to pressure on its resources by concentrating on "urgent" missions, but that it was now trying harder to balance these against longer-term concerns, such as science and technology.

The department has already asked the national academy for advice on how it can better integrate science and technology into its sprawling operations (see Nature 392, 427; 1998). Glenn Schweitzer of the academy's international office says that, although a committee is yet to be appointed, its study will produce a short report by September to feed into next year's budget process. Its main report will follow in 1999.

Schweitzer told a meeting of the President's Council of Advisors on Science and Technology (PCAST) last week that, after 15 meetings with state department officials, he believed that there was "genuine interest at the political level and some interest among the career staff" in the outcome of the study.

Wendy Sherman, a counsellor in the office of Madeline Albright, the secretary of state, was unenthusiastic about the suggestion from one PCAST member that the state department could learn something from its counterparts abroad.

"Other countries aren't expected to carry the same range of responsibilities," she said. "It is probably easier for some of them to put more effort into science and technology because they don't have to cover the entire waterfront."

At a congressional hearing in March, it was suggested that the state department should take a leaf out of other nations' books by hiring science attachés on secondment from science agencies, rather than relying on career diplomats.

Colin Macilwain

\section{Senate's proposed budget increases disappoint NSF and NASA}

[WASHINGTON] The US Senate Appropriations Committee last week approved modest budget increases in the next financial year, which starts on 1 October, for the National Science Foundation (NSF) and the NASA space agency. But, for both agencies, this first step in the annual congressional budget process was a minor disappointment.

For example, although the senators proposed giving $\$ 3.64$ billion to the NSF next year, a 6.3 per cent increase on this year, it is $\$ 129$ million less than had been requested by the Clinton administration.

The White House had proposed a 12 per cent increase for the research account that funds individual grants to scientists, but the Senate committee recommends giving \$2.7 billion, an increase of only 7 per cent. Included in that are more than $\mathbf{\$ 5 0}$ million in targeted 'earmarks', which would further dilute spending on basic research grants.

The earmarked funding includes an additional \$24 million for logistics support of Arctic research, whereas the NSF had asked for only $\$ 9.5$ million. The senators would also give $\$ 50$ million to research into plant genomes, $\$ 10$ million more than the agency requested.

Two important projects, the Large Hadron Collider and the Millimeter Array telescope, would be fully funded. But the Senate committee denied a $\$ 25$ million request for the Polar Cap Observatory, which has been turned down for two years running by Senator Ted Stevens (Republican, Alaska), chairman of the appropriations committee. Stevens wants the observatory built on US territory, not in Canada as the NSF recommends.

The agency was also denied a 5 per cent increase for salaries and expenses, most of which was aimed at converting the 'FastLane' electronic grants administration system to full operational status.

The Senate committee recommended boosting NASA's budget request by $\$ 150$ million to $\$ 13.6$ billion. Space science would receive $\$ 50$ million of this increase, including a $\$ 20$ million boost for the Mars exploration programme. Earth sciences would receive \$25 million more than NASA asked for, and life and microgravity sciences would get the amount requested.

Perhaps more important than the actual increases, the senators strongly warned NASA against "raiding" other parts of its budget to bail out the financially troubled space station. They also restructured the appropriations accounts in part "to ensure that Congress and this subcommittee gets honest figures for the [station]," according to Senator Christopher Bond (Republican, Missouri), who heads the NASA-NSF appropriations panel.

Funding for the space station, space science and aeronautics would now have separate congressional budgets. But NASA is expected to protest against this restructuring.

Both agencies will have further opportunities to plead their case. The full Senate is expected to vote on the appropriations bill later this month. Appropriations committee members in the House of Representatives will write their own funding bill this week, and the two versions will be reconciled into a final bill in the autumn.

Tony Reichhardt 